\title{
CORRELATION AND PATH ANALYSIS IN SUNFLOWER (Helianthus annuus L.)
}

\author{
Biljana Gorgieva ${ }^{1}$, Ilija Karov ${ }^{2}$, Sasa Mitrev ${ }^{2}$, Natalija Markova Ruzdik ${ }^{2}$, Emilija Kostadinovska ${ }^{2}$ and Biljana \\ Kovacevik $^{2}$ \\ ${ }^{1}$ Agency for food and veterinary, 2300 Kocani, Republic of Macedonia \\ ${ }^{2}$ Faculty of Agriculture, "Goce Delchev" University, 2000 Shtip, Republic of Macedonia
}

\section{SUMMARY}

This study was carried out to determine the correlation between agronomic traits and seed yield of sunflower cultivars and also to determine the direct and indirect effect of analyzed traits on seed yield. The primary task in sunflower breeding programs is increasing the seed yield and creates new hybrids with high potential for seed and oil yield.

Field trials were set up according to randomized block design during two growing seasons (2013 and 2014), on research area of Faculty of Agriculture, "Goce Delchev" University in Ovche Pole locality, Republic of Macedonia. As an experimental material were used 20 sunflower varieties. 1000 seed weight, length and width of grain, oil content, oleic acid content and seed yield were analyzed. For 1000 seed weight was obtained highly positive and significant correlation with seed yield and grain width. On the other hand, 1000 seed weight showed negative and significant correlation with oil content. This trait expressed the biggest positive direct effect on seed yield.

\section{Key words: sunflower, correlation coefficient, path analysis, agronomic traits}

\section{INTODUCTION}

Sunflower (Helianthus annuus L.) is an important crop, primarily grown for oil which is used for human consumption, but also as a row material in industry (Mijić et al., 2009). The main objective of any plant breeder includes the highest seed yield and oil content (Vrânceanu et al., 2005). The success of breeding programs primarily depends on the variation present for yield and yield components as well as nature of initial material (Nehru and Manjunath, 2003). Indirect selection using yield components may increase seed yield of sunflower varieties. Fick et al. (1974) reported correlation between seed yield and many agronomic traits.

Seed yield in sunflower is a complex quantitative trait controlled by large number of genes and is highly influenced by environmental, morphological and physiological properties. On the other side, the seed yield is a function of genetic potential of the variety, external conditions in which the crop is grown, applied technology and the interaction of all these factors (Abad et al., 2013). Sunflower seed yield, like other crops, is a function of many traits which have interrelation among them and affect the grain yield directly or indirectly. 
Many researchers used correlation coefficient and path analysis to determine the relationship among seed yield and other agronomic traits (Kaya and Atakisi, 2003; Kaya et al., 2003; Nehru and Manjunath, 2003; Joksimovic et al., 2004; Nistor et al., 2005; Sridhar et al., 2005; Farhatullah, and Khalil, 2006; Goksoy and Turan, 2007; Machikowa and Saetang, 2008; Kaya et al., 2009; Mijić et al., 2009). Correlation coefficient is very important to define the traits that directly affect to the seed yield.

The path coefficient analysis is one of the statistical tools which is used to determine the direct or indirect effects of any yield component on grain yield. Correlation coefficient and path coefficient analysis assist to identify the traits that are useful as selection criteria to improve seed yield.

The objectives of this research were to determine the correlation among seed yield and some agronomic traits and to determine the direct and indirect effects of certain traits on seed yield in sunflower varieties.

\section{MATERIALS AND METHODS}

The experimental material included 20 sunflower genotypes (NLK12M006, NLK12M008, NLK12M009, NLK12M058, NLK12M59, NLK12M063, NLK12M134, NLK12M139, NLK12M144, NLK12M148, NLK12S070, NLK12S074, NLK12S125, NLK12S126, NLN11001, NLN12N005, NLN12N007, NLN12N010 DMR, NLN12N011 DMR and NSK12001). The field trials were set up during the 2013 and 2014 on the research area of Faculty of Agriculture, "Goce Delchev" University in Ovche Pole locality, Republic of Macedonia. The sunflower varieties were planted in randomized complete block design with three replications. Each experimental plot was $6 \mathrm{~m}$ long, consisted of 4 rows, with 24 plants in one row. The seeds were sown by the sowing machine at a spacing of $0.30 \mathrm{~m}$ within the rows and $0.60 \mathrm{~m}$ between the rows. In first year of setting the experiment (2013), the previous crop was wheat and in the second experimental year (2014) barley. First experimental year the sowing occurred on 19 April and in the second year on 15 April. The standard growing measures were applied during the period of vegetation. The trial was treated with herbicide Goal in the second half of April. Diseases and insects were controlled by regular applications of fungicides and insecticides. There was not applied addition irrigation during the planting season. The harvest was done by hand. Following traits were analyzed: 1000 seed weight $(\mathrm{g})$, grain length and width $(\mathrm{mm})$, oil content (\%), oleic acid content (\%) and seed yield $(\mathrm{kg} / \mathrm{ha})$. The result for seed yield was collected separately from each plot and convert from a per plot to a per hectare. To determine the oil content and oleic acid, nuclear magnetic resonance was used.

Obtained results were statistically analyzed by using statistical software (Stat Soft, 8.0). The correlation between seed yield and some agronomic traits on all sunflower genotypes was determined by using linear correlation (Singh and Chaudhary, 1985), with SSPS statistics 19 (2010). Direct and indirect effects of the agronomic 
characteristics on seed yield were calculated by the path analysis (Dewey and Lu, 1959).

In Table 1 are given the weather characteristics of Ovche Pole locality for the period of study, as well as data for long term period (2001-2012). The average value of the temperature in the first year of testing (2013) was $18.9^{\circ} \mathrm{C}$. It was $0.7{ }^{\circ} \mathrm{C}$ higher in comparison with the average value for temperature in the second experimental year and $0.6{ }^{\circ} \mathrm{C}$ lower than the annual average. The average monthly air temperature in the second year of the study (2014) was $18.1^{\circ} \mathrm{C}$ and it was lower by $1.4^{\circ} \mathrm{C}$ compared with the average of the multi-period (2001-2012).

Generally, the average monthly temperature in the first experimental year (2013) in all months was higher than in the second year except in July. Average monthly temperatures in 2013 were also higher in comparison with average monthly temperatures from long term period except in June, July and October. Table 1 show that in the second experimental year (2014), in all months the average air temperatures were lower compared to average monthly temperatures from the long term period. There were no significant differences between the average monthly temperatures in first and in the second experimental year (Table 1).

Significant differences exist in terms of the amount of precipitation (Table 1). The amount of rainfall during the vegetation in the first experimental year was $202.6 \mathrm{~mm}$ and is less than the $330.2 \mathrm{~mm}$ compared with the amount of precipitation in the second experimental and $117.3 \mathrm{~mm}$ less than the amount of precipitation of the multi-period. The amount of precipitations in the second year was also higher for $212.9 \mathrm{~mm}$ compared with the amount of precipitation of the multi-period.

Significant amounts of monthly rainfall in the second year of the examination were recorded in April $(148.2 \mathrm{~mm})$ and September $(142.3 \mathrm{~mm})$. Overall monthly amount of rainfall this year was higher in all months compared with the monthly amount of rainfall in the first year of testing. Higher doses of precipitation were registered in comparison with monthly precipitation of annual average except in August and October. The monthly amount of rainfall in the first year only in April and September was higher compared with monthly precipitation of annual average. 
Table 1. Average monthly temperature $\left({ }^{\circ} \mathrm{C}\right)$ and monthly amount of precipitations (mm) for period of study and long term period in Ovche Pole locality

\begin{tabular}{|c|c|c|c|c|c|c|c|c|}
\hline \multicolumn{8}{|c|}{ Average monthly temperature ( $\left.{ }^{\circ} \mathbf{C}\right)$} \\
\hline & IV & V & VI & VII & VIII & IX & X & Average/Sum \\
\hline $\mathbf{2 0 0 1 - 2 0 1 2}$ & 12.9 & 18.0 & 22.5 & 25.2 & 24.7 & 19.4 & 13.8 & 19.5 \\
\hline $\mathbf{2 0 1 3}$ & 13.2 & 18.6 & 21.7 & 20.9 & 25.0 & 19.6 & 13.0 & 18.9 \\
\hline $\mathbf{2 0 1 4}$ & 12.2 & 16.6 & 20.3 & 23.3 & 24.1 & 17.9 & 12.5 & 18.1 \\
\hline \multicolumn{8}{|c|}{ Monthly amount of precipitations (mm) } \\
\hline $\mathbf{2 0 0 1 - 2 0 1 2}$ & 40.0 & 56.1 & 48.5 & 30.2 & 39.4 & 37.6 & 68.1 & 319.9 \\
\hline $\mathbf{2 0 1 3}$ & 63.2 & 44.8 & 23.8 & 4.9 & 3.3 & 50.8 & 11.8 & 202.6 \\
\hline $\mathbf{2 0 1 4}$ & 148.2 & 59.3 & 69.3 & 53.5 & 6.7 & 142.3 & 53.5 & 532.8 \\
\hline
\end{tabular}

\section{RESULTS AND DISCUSSION}

The data from descriptive analysis for seed yield and other agronomic traits of 20 sunflower genotypes are given in Table 2. Genotype NLK12M144 has the highest average value for seed yield ( $3344 \mathrm{~kg} / \mathrm{ha}$ ). The average value for seed yield during the period of study was $2721 \mathrm{~kg} / \mathrm{ha}$. According to Kaya et al. (2009) the seed yield of sunflower hybrids ranged between 800 - $4250 \mathrm{~kg} / \mathrm{ha}$ with average value $2160 \mathrm{~kg} / \mathrm{ha}$. Higher values for this trait were presented by Mijić et al. (2009).

Usually the content of oleic acid in sunflower cultivars is present with $20 \%$ of fatty acid composition. In commercial sunflower hybrids the values for oleic acid range between $10-50 \%$, primarily depends of the air temperature during the growing period (Pãcureanu - Joipa et al., 1999). In our study the average value for oleic acid content from both years was $65.2 \%$.

Oil content in sunflower varieties depends of genetic potential and environmental conditions (Hlandi et al., 2006). According to Škorić et al. (1996) oil content in sunflower genotypes rang between $38.1 \%-49.2 \%$. In this research the average value for oil content during the period of study was $45.6 \%$.

The maximum coefficient of variation was obtained for seed yield and 1000 seed weight, $12.16 \%$ and $12.08 \%$, respectively. According to Kholghi et al. (2011) the coefficient of variation for seed yield was higher (42.07\%).

Table 2. Descriptive statistics for agronomic traits in sunflower varieties during the period of study

\begin{tabular}{|c|c|c|c|c|c|c|}
\hline Variety/Trait & $\begin{array}{c}\mathbf{1 0 0 0} \\
\text { seed } \\
\text { weight }(\mathbf{g})\end{array}$ & $\begin{array}{c}\text { Grain } \\
\text { length } \\
\mathbf{( \mathbf { m m } )}\end{array}$ & $\begin{array}{c}\text { Grain } \\
\text { width } \\
\mathbf{( m m})\end{array}$ & $\begin{array}{c}\text { Oil } \\
\text { content } \\
\mathbf{( \% )}\end{array}$ & $\begin{array}{c}\text { Oleic acid } \\
\text { content } \\
\mathbf{( \% )}\end{array}$ & $\begin{array}{c}\text { Seed } \\
\text { yield } \\
\text { (kg/ha) }\end{array}$ \\
\hline NLK12M006 & 75.45 & 10.98 & 6.06 & 42.9 & 68.1 & 2908 \\
\hline NLK12M008 & 73.36 & 10.22 & 6.21 & 45.3 & 67.6 & 2870 \\
\hline NLK12M009 & 70.42 & 10.25 & 6.31 & 44.8 & 66.3 & 2762 \\
\hline NLK12M058 & 78.34 & 12.15 & 5.87 & 46.1 & 64.6 & 2575 \\
\hline NLK12M059 & 75.38 & 11.76 & 5.77 & 47.2 & 66.4 & 2577 \\
\hline NLK12M063 & 78.61 & 11.13 & 5.46 & 45.0 & 69.8 & 2485 \\
\hline
\end{tabular}




\begin{tabular}{|c|c|c|c|c|c|c|}
\hline NLK12M134 & 72.28 & 11.64 & 6.32 & 44.7 & 64.9 & 3024 \\
\hline NLK12M139 & 62.79 & 10.80 & 5.88 & 47.5 & 64.5 & 2991 \\
\hline NLK12M144 & 57.78 & 10.19 & 5.70 & 49.1 & 63.1 & 3344 \\
\hline NLK12M148 & 69.20 & 11.09 & 6.01 & 44.4 & 75.8 & 2376 \\
\hline NLK12S070 & 85.29 & 11.68 & 6.90 & 44.3 & 68.0 & 2644 \\
\hline NLK12S074 & 76.69 & 10.82 & 6.13 & 46.8 & 87.1 & 2264 \\
\hline NLK12S125 & 83.95 & 11.68 & 6.93 & 41.3 & 68.4 & 2748 \\
\hline NLK12S126 & 87.83 & 11.97 & 7.01 & 41.8 & 74.8 & 2244 \\
\hline NLN11001 & 81.49 & 10.26 & 6.39 & 48.5 & 48.4 & 2737 \\
\hline NLN12N005 & 87.63 & 11.34 & 6.69 & 46.2 & 39.4 & 3047 \\
\hline NLN12N007 & 80.21 & 11.32 & 6.51 & 43.5 & 57.4 & 2914 \\
\hline NLN12N010 DMR & 78.64 & 11.54 & 6.02 & 48.5 & 51.5 & 2924 \\
\hline NLN12N011 DMR & 87.36 & 11.67 & 6.32 & 45.0 & 51.0 & 2282 \\
\hline NSK12001 & 56.67 & 10.36 & 5.92 & 49.1 & 87.2 & 2707 \\
\hline Average & $\mathbf{7 5 . 9 7}$ & $\mathbf{1 1 . 1 4}$ & $\mathbf{6 . 2 2}$ & $\mathbf{4 5 . 6}$ & $\mathbf{6 5 . 2}$ & $\mathbf{2 7 2 1}$ \\
\hline Min. & $\mathbf{5 6 . 6 7}$ & $\mathbf{9 . 0 6}$ & $\mathbf{4 . 0 7}$ & $\mathbf{3 8 . 1}$ & $\mathbf{3 6 . 4}$ & $\mathbf{2 ~ 2 4 4}$ \\
\hline Max. & $\mathbf{8 7 . 8 3}$ & $\mathbf{1 3 . 4 5}$ & $\mathbf{8 . 5 1}$ & $\mathbf{5 0 . 3}$ & $\mathbf{8 9 . 0}$ & $\mathbf{3 3 4 4}$ \\
\hline CV (\%) & $\mathbf{1 2 . 0 8}$ & $\mathbf{5 . 1 0}$ & $\mathbf{7 . 2 8}$ & $\mathbf{3 . 7 3}$ & $\mathbf{6 . 4 0}$ & $\mathbf{1 2 . 1 6}$ \\
\hline
\end{tabular}

The correlation coefficient between seed yield and other agronomic traits are presented in Table 3. In this study highly significant positive and negative correlation were obtained. The highest correlation coefficient was found between 1000 seed weight and grain width (positive) and between oil content and grain width (negative).

1000 grain weight directly influence on seed yield (Morozov, 1970). 1000 seed weight showed significant and positive correlation with grain width $(r=0.638)$ and seed yield $(r=0.413)$. Similar significant positive coefficient between 1000 seed weight and seed yield was also observed by Joksimović et al. (2004), Kaya et al. (2009), Mijić et al. (2009) and Anandhan et al. (2010).

Sunflower oil is a high qualitative one, with high percentage of unsaturated fatty acids which can achieve $90 \%$ from the total (Kinman and Earle, 1964). Significant and negative correlation was obtained between 1000 seed weight and oil content $(r=-$ 0.563). The similar results were reported by Joksimović et al. (2004), Kaya et al. (2007) and Mijić et al. (2009).

In this paper among grain length and oleic acid content was determined negative and significant correlation $(r=-0.507)$ at level of significance of 0.05 . Negative and significant correlation was observed between oil content and grain width $(r=-0.661)$ at level of significance of 0.01 .

The correlation coefficients among other analyzed traits were not significant. 
Table 3. Correlation coefficient of seed yield and some agronomical traits

\begin{tabular}{|l|r|r|r|r|r|r|}
\hline \multicolumn{1}{|c|}{ Trait } & $\begin{array}{c}\text { 1000 seed } \\
\text { weight }\end{array}$ & $\begin{array}{c}\text { Grain } \\
\text { length }\end{array}$ & $\begin{array}{c}\text { Grain } \\
\text { width }\end{array}$ & Oil content & $\begin{array}{c}\text { Oleic acid } \\
\text { content }\end{array}$ & Seed yield \\
\hline 1000 seed weight & $\mathbf{1}$ & & & & & \\
\hline Grain length & 0.361 & $\mathbf{1}$ & & & & \\
\hline Grain width & $\mathbf{0 . 6 3 8 ^ { * * }}$ & 0.290 & $\mathbf{1}$ & & & \\
\hline Oil content & $-\mathbf{0 . 5 6 3}$ & -0.008 & $-\mathbf{0 . 6 6 1}$ & $\mathbf{1}$ & & \\
\hline Oleic acid content & -0.436 & $-\mathbf{0 . 5 0 7}$ & -0.165 & -0.126 & $\mathbf{1}$ & \\
\hline Seed yield & $\mathbf{0 . 4 1 3 ^ { * }}$ & 0.219 & -0.119 & 0.326 & -0.412 & $\mathbf{1}$ \\
\hline
\end{tabular}

*, ${ }^{* *}$ Statistical significance at $\mathrm{P}<0.05$ and $\mathrm{P}<0.01$

Propose of using the path coefficient analysis in this study was to obtain further information about the interrelationships between the seed yield and other agronomic traits and about the influence of them on seed yield. In Table 4 is presented the direct and indirect effect of traits on seed yield.

In our study, path coefficient analysis showed that 1000 seed weight has the highest direct positive effect on seed yield. Similar results were obtained by Merrien et al. (1982), Nehru and Manjunath (2003). These results indicate that an increase of 1 000 seed weight causes some increase in sunflower seed yield.

Indirect positive effect on seed yield was obtained for oleic acid content and the highest negative indirect effect was determined for oil content.

Table 4. Direct and indirect effects of agronomic traits on seed yield

\begin{tabular}{|c|c|c|c|c|c|c|c|}
\hline \multirow[b]{2}{*}{ Indicators } & \multirow{2}{*}{$\begin{array}{l}\text { Direct } \\
\text { effect }\end{array}$} & \multicolumn{5}{|c|}{ Indirect effect } & \multirow{2}{*}{$\begin{array}{c}\text { Total } \\
\text { indirect } \\
\text { effect }\end{array}$} \\
\hline & & $\begin{array}{c}1000 \text { seed } \\
\text { weight }\end{array}$ & $\begin{array}{l}\text { Grain } \\
\text { length }\end{array}$ & $\begin{array}{l}\text { Grain } \\
\text { width }\end{array}$ & $\begin{array}{c}\text { Oil } \\
\text { content }\end{array}$ & $\begin{array}{c}\text { Oleic acid } \\
\text { content }\end{array}$ & \\
\hline $\begin{array}{c}1000 \text { seed } \\
\text { weight }\end{array}$ & 0.413411 & & -0.14924 & -0.26376 & 0.14849 & 0.18025 & -0.08426 \\
\hline $\begin{array}{l}\text { Grain } \\
\text { length }\end{array}$ & -0.218784 & -0.07898 & & -0.06345 & 0.00175 & 0.11092 & -0.02975 \\
\hline $\begin{array}{l}\text { Grain } \\
\text { width }\end{array}$ & -0.118546 & -0.07563 & -0.03438 & & 0.07836 & 0.01956 & -0.01209 \\
\hline Oil content & 0.325851 & -0.18345 & -0.00261 & -0.21539 & & -0.04106 & -0.44251 \\
\hline $\begin{array}{c}\text { Oleic acid } \\
\text { content }\end{array}$ & -0.412071 & 0.17966 & 0.20892 & 0.06799 & 0.05192 & & 0.50850 \\
\hline
\end{tabular}

\section{CONCLUSION}

The path coefficient analyses allowed us to detect those traits witch have the greatest positive and negative influence on seed expression. From the results, 1000 seed weight has shown the strongest direct positive effect on seed yield. Positive direct effect of this trait was associated with highly significant and positive correlations with seed yield. It can be conclude that this trait can be good selection criteria for achieving improvement for seed yield of sunflower varieties. 


\section{REFERENCES}

Abad, A., Khajehpour, M.R., Mahloji, M. and Soleymani, A., 2013. Evaluation of phonological, morphological and physiological traits in different lines of barley in Esfahan region. International Journal of Farming and Applied Science 2(18): 670-674.

Anandhan, T., Manivannan, P., Vindhiyavarman, P. and Jeyakumar, P., 2010. Correlation for oil yield in sunflower (Helianthus annuus L.). Electronic Journal of Plant Breeding 1(4): 869871.

Dewey, D.R. and Lu, K.H., 1959. A correlation and path coefficient analysis of components of crested wheat grass grain production. Journal of Agronomy 51: 515-518.

Farhatullah, F. and Khalil, I.H., 2006. Path analysis of the coefficients of sunflower (Helianthus annuus L) hybrids. International Journal of Agriculture and Biology 8: 621-625.

Fick, G.N., Zimmer, D.E. and Zimmerman, D.C., 1974. Correlation of seed oil content in sunflower with other plant and seed characteristics. Crop Science 14: 755-757.

Goksoy, A.T. and Turan, Z.M., 2007. Correlations and path analysis of yield components in synthetic varieties of sunflower (Helianthus annuus L.). Acta Agronomica Hungarica 10: 339-345.

Hladni, N., Škorić, D., Kraljevic-Balalic, K., Sakac, Z. and Jovanovic, D., 2006. Combining ability for oil content and its correlation with other yield components in sunflower $(\mathrm{H}$. annuus L.). Helia 29(44): 101-110.

Joksimovic, J., Atlagic, J., Jovanovic, D., Marinkovic, R., Dusanic, N. and Miklic, V., 2004. Path coefficient analysis of some head and seed components in sunflower. Proceeding of 16th International Sunflower Conference. Fargo, ND, US, 525-530.

Kaya, Y. and Atakisi, I.K., 2003. Path and correlation analysis in different yield components in sunflower (H. annuus L). Anadolu Journal 13: 31-45.

Kaya, Y., Evci, G., Durak, S., Pekcan, V. and Gucer, T., 2007. Determining the relationships between yield and yield attributes in sunflower. Turkish Journal of Agriculture and Forestry 31: 237-244.

Kaya, Y., Evci, G., Durak, S., Pekcan, V. and Gucer, T., 2009. Yield components affecting seed yield and their relationship in sunflower (Helianthus annuus L.). Pakistan Journal of Botany 41(5): 2261-2269.

Kaya, Y., Evci, G., Pekcan, V. and Gucer, T., 2003. The determination of the contribution on important yield components to seed and oil yield in sunflower. Proceeding of 5th Turkish Field Crops Congress, Diyarbakır, Turkey, 120-125.

Kholghi, M., Bernousi, I., Darvishzadeh, R., Pirzad, A. and Maleki, HH., 2011. Collection, evaluation and classification of Iranian confectionary sunflower (Helianthus annuus L.) populations using multivariate statistical techniques. African Journal of Biotechnology 10(28): 5444-5451.

Kinman, M.L. and Earle, F.R., 1964. Agronomic performances and chemical composition of the seed of sunflower hybrids and introduced varieties. Crop Science 4(4): 417- 420.

Machikowa, T. and Saetang, C., 2008. Correlation and path coefficient analysis on seed yield in sunflower. Journal of Science and Technology 15(3): 243-248. 
Merrien, A., Blanchet, R., Gelfi, N., Rellier, J.P. and Rollier, M., 1982. Voies d élaboration du rendement chez le tournesol sous différents stress hydriques. Procendings of 10 th International Sunflower Conference 1:1-14.

Mijić, A., Liović, I., Zdunić, Z., Marić, S., Marjanović Jeromela, A. and Jankulovska, M., 2009. Quantitative analysis of oil yield and its components in sunflower (Helianthus annuus L.). Romanian Agriculture Research 26: 41-46.

Morozov, V.K., 1970. On sunflower selection for yield. Selection and Seed Production 1: 18-25.

Nehru, S.D. and Manjunath, A., 2003. Correlation and Path Analysis in Sunflower (Helianthus annuus L.). Journal of Agriculture and Science 16(1): 39-43.

Nistor, T., Sturzu, R., Nistor, G., Mîrlogeanu, S. and Anghel, J., 2005. Genetic control of the agronomically useful genetic traits in cotton. Romanian Agricultural Research 22: 27-32.

Pãcureanu - Joipa, M., Viorel Vrânceanu, A., Stanciu, D. and Raranciuc, S., 1999. High oleic acid content in sunflower genotypes in relation with resistance to diseases. Romanian Agricultural Research 11-12: 21-27.

Singh, R.K. and Chaudhary, B.D., 1985. Biometrical Methods in Quantitative Genetics Analysis. Kalyani Publishers, New Delhi, 318.

Škorić, D., Mihaljčević, M., Jocić, S., Marinković, R., Dozet, B., Atlagić, J. and Hladni, N., 1996. Najnovija dostignuća u oplemenjivanju suncokreta. u: Savetovanje o proizvodnji i preradi uljarica 37: 18-25.

SPSS Statistics 19. 2010. SPSS Inc., an IBM Company.

Sridhar, V., Dangi, K.S., Reddy, V.A. and Kumar, S.S., 2005. Character association and path analysis in sunflower (Helianthus annuus L.). Crop Research 30: 63-67.

Vrânceanu, A.V., Stanciu, D., Stanciu, M., Păcureanu-Joiţa, M., Şorega, I. and Mantu, I., 2005. Jupiter - a new Orobanche resistant sunflower hybrid. Romanian Agricultural Research 22: 19-22.

Corresponding author: e-mail: bgorgieva@yahoo.com 